\title{
ECONOMICS OF BLACK GRAM CULTIVATION AND ITS IMPACT ON FARMERS LIVELIHOOD IN TWO SELECTED DISTRICTS OF BANGLADESH
}

\author{
M. Mohiuddin ${ }^{1 *}$, N. Akter ${ }^{2}$ and R. Khanum ${ }^{3}$ \\ ${ }^{1}$ Agricultural Research Sub-station, OFRD, BARI, Kishoreganj, Bangladesh \\ ${ }^{2}$ On-Farm Research Division, Mymensingh, Bangladesh \\ ${ }^{3}$ Department of Agricultural Economics and Policy, Sylhet Agricultural University, Sylhet, Bangladesh
}

\begin{abstract}
The present study is an attempt to assess the existing agronomic practices of black gram cultivation, its impact on farmers livelihood and constraints of black gram production and marketing. Primary data from 85 farmers were collected during February to March 2016 through face to face interviews. Descriptive statistics and Garret ranking method were used to analyze the data. The majority of the farmers had sown seeds during the last week of September to first week of October. The average seed rate was found to be $19.36 \mathrm{~kg}$ per hectare which indicated that all farm households used below recommended dose of seeds (35-40 $\mathrm{kg} / \mathrm{ha}$ ). The average yield of black gram was found higher than the national average. The average net income was observed to be Tk. 26990 and Tk. 19845 in Sherpur and Jamalpur respectively. The average gross margin was observed to be Tk. 37629 on total variable cost basis. It was also found that average returns to labour was Tk. 1000/man-day in Sherpur and Tk. 692/man-day in Jamalpur district respectively. It was also observed that all kinds of livelihood assets of the selected farmers increased significantly through black gram farming. The results revealed that the main constraints faced by black gram grower were lack of irrigation facility, non availability of HYV seeds, low output price, labour scarcity, lack of knowledge about improved varieties with their production technology, excessive rainfall after flowering and weak research-extension farmers linkage etc. Farmers also faced some marketing related problems such as limited buyers, price instability, lack of storage facilities and high market toll. Farmers cultivated black gram because of higher yield, higher income, and easy growing.
\end{abstract}

Keywords: Black gram, garret method, farmers livelihood

\footnotetext{
* Corresponding author email: mmohiuddin@bari.gov.bd
} 


\section{INTRODUCTION}

Agricultural sector is the backbone of Bangladesh economy providing employment to $45 \%$ of the total population and contributes about $14.79 \%$ of GDP (BER, 2017). Pulses constitute an integral part of human diet and are potential source of protein for the millions of people of Bangladesh. Pulses provide significant nutritional and health benefits, and are known to reduce several non-communicable diseases such as colon cancer and cardiovascular diseases (Yude et al, 1993; Jukanti et al, 2012).

They contribute $2.3 \%$ value added to agriculture in Bangladesh (Niaz et al., 2013). Pulses are considered as "the meat of the poor" because still pulses are the cheapest source of protein (Hamjah, 2014). Pulses are popular and common food, people take this food almost alternate a day, so, this can play an important role to reduce the malnutrition for the poor people of the country if it becomes available to that type of people. The per capita consumption of pulse in Bangladesh is only $14.3 \mathrm{~g} \mathrm{day}^{-1}$, which is much lower than WHO recommendation of $45 \mathrm{~g} \mathrm{day}^{-1}$ and Indian Council of Medical Research recommendation of $60 \mathrm{~g} \mathrm{day}^{-1}$ (HIES, 2010; Afzal et al., 1999). With the increase production of nutrient-rich crops like more pulses and oilseeds, farmers can ensure reduction of poverty at grass root-level with increase nutritional food security at local levels (Rahman and Zilani, 2009). Among the pulses, Blackgram is very much popular in Bangladesh and ranks $3^{\text {rd }}$ in terms of consumption and total area in which different varieties of this crop are cultivated (BBS, 2014). Black gram is very nutritious as it contains high levels of protein (25 $\mathrm{g})$, potassium $(983 \mathrm{mg})$, calcium $(138 \mathrm{mg})$, iron $(7.57 \mathrm{mg})$, niacin $(1.447 \mathrm{mg})$, thiamine $(0.273 \mathrm{mg})$, and riboflavin $(0.254 \mathrm{mg})$ per $100 \mathrm{~g}$. Among the pulses, 45-50 $\%$ area covered by black gram in Jamalpur and $75-80 \%$ area in Sherpur district. Total cultivated area in Bangladesh is 9805360 hectares of which $44.63 \%, 18.28 \%$ and $10.20 \%$ are suitable, moderately suitable and marginally suitable for black gram production (BARC, 2016).

An estimated 6.5 million people live on the char and associated erosion and flood prone areas which are $5 \%$ of the total population of Bangladesh. On the other hand, total char area is 5\% of the total land area of Bangladesh (EGIS 2000) where in Jamalpur and Sherpur district, it covers $40-42 \%$ and pulse crops grown mainly in this char land. In the existing farming systems, pulse crops fit well due to its short duration, drought tolerance, less care and minimum input requirement. Cultivation of different pulses is decreasing day by day. According to department of agricultural extension, pulse area decreased 15-20\% in year 2013-14 from year 2012-2013 in Jamalpur and 30-36\% area decreased in year 2013-2014 from year 2010-2011 at Sherpur district respectively. Not only that the country is facing acute shortage of 
pulses due to accelerated increase of requirements with its rapid population growth. But price of pulses increasing and government of Bangladesh spent more foreign exchange every year in importing pulses to meet up the local demand. Though, pulses are excellent sources of proteins, but they are treated as minor crops and receive little attention from farmers and policymakers. So the decrease in pulse production is a major concern to the government. Considering the above circumstances, pulse production should be increased rapidly to improve the national nutritional status along with less outflow of precious foreign currency.

Many studies (Miah et al., 2004; Islam et al., 2011, 2013 and 2015; Kumar et al., 2009-2010; Gowda et al., 2013; Kumar and Bourai, 2012; Hamjah, 2014; Niaz et al., 2013) focusing on different pulse crop have been conducted earlier in Bangladesh and India are very general and consider the problem from national or regional points of view while no work has been done to understand the problems of black gram in specific locations or districts of Bangladesh. For these reasons, the present study has been undertaken to know the economy of black gram cultivation and its impact on farmers livelihood in Jamalpur and Sherpur districts.

\section{MATERIALS AND METHODS}

The present study was conducted in purposively selected two black gram cultivated upazila in Sherpur and Jamalpur district on the basis of maximum area under this crop. Simple random sampling techniques was followed to select the sample size. At first, in each district one upazila (Nakla upazila of Sherpur and Jamalpur sadar upazila of Jamalpur) and from each upazila two char villages were selected based on intensive black gram producing areas in consultation with upazila agricultural officer and Sub Assistant Agricultural Officer to collect primary data and information. Then, a list of all black gram growers in each selected villages was prepared and finally, a total of 85 farmers taking 40 from Sherpur and 45 from Jamalpur district was randomly selected. Primary data were collected by using a predesigned and pre-tested questionnaire in February-March, 2016. The impact on livelihoods was measured through finding comparative position of physical, social, financial, human and natural assets of the farmers before and after adoption of the intervention. The collected data was coded, edited, summarized, tabulated and analyzed to fulfill the objectives of the study. Labour use efficiency was measured to see the rate of return from labour employed by using the following formula as Huq et al., (1998).

Return to labour $=\frac{\text { Grossreturn }- \text { All } \cos \text { t except } \cos t \text { of labour }}{\text { No.of labour employed }}$

\section{Constraint analysis}

The Garrett's Ranking Technique (Mahesh, 2000) was used to rank the constraints for both production and marketing of black gram. As per this method, respondents have 
been asked to assign the rank for all factors and the outcome of such ranking has been converted into score value with the help of the following formula:

$\%$ position $=100\left(\mathrm{R}_{\mathrm{ij}}-0.50\right) / \mathrm{N}_{\mathrm{j}}$

Where,

$\mathrm{R}_{\mathrm{ij}}=$ Rank given for $\mathrm{i}^{\text {th }}$ factor by $\mathrm{j}^{\text {th }}$ individual

$\mathrm{N}_{\mathrm{j}}=$ Number of factors ranked by $\mathrm{j}^{\text {th }}$ individual

The $\%$ position of each rank thus obtained was converted into scores by referring to the table given by Garrett. Then for each factor, the scores of each individual are added and then total value of scores and mean values of score is calculated. The factors having highest mean value is considered to be the most important factor.

\section{RESULTS AND DISCUSSION}

\section{Level of technology used}

For achieving higher yield and profitability, appropriate input use and time of operation is important. It is revealed that the number of ploughing varied from farm to farm and location to location. About $13.04 \%$ and $17.86 \%$ farmers ploughed their land to cultivate black gram in Sherpur and Jamalpur district, respectively (Table 1). Rest of the farmers produced black gram without ploughing their lands. Ploughing on the survey plot started in the $3^{\text {rd }}$ week of September. In all areas, farmers ploughed their lands with the help of power tiller.

Table 1. Distribution of $\%$ of farmers according to land preparation

\begin{tabular}{l|c|c|c}
\hline \multirow{2}{*}{ Location } & \multicolumn{2}{|c|}{ Land preparation (ploughing) } & \multirow{2}{*}{$\begin{array}{c}\text { Variance between } \\
\text { respondents }\end{array}$} \\
\cline { 2 - 3 } & With & Without & \\
\hline Sherpur & 13.04 & 86.96 & $2.02 \%$ \\
Jamalpur & 17.86 & 82.14 & $10.09 \%$ \\
\hline
\end{tabular}

\section{Sowing of seeds}

Farmers followed broad casting method for sowing black gram seeds in all areas. Maximum farmers sowed the seeds during last week of September to first week of October (Table 2). After removal of water from their land, farmers broad casted black gram seeds in their field. The time of seed sowing depended on when flood waters receded. As there was sufficient moisture available in the soil, ploughing did not have much effect on yields. 
Table 2. Distribution of farmers according to different dates of sowing

\begin{tabular}{|c|c|c|c|c|}
\hline \multicolumn{2}{|c|}{ Date of sowing } & Sherpur & Jamalpur & Variance between respondents \\
\hline Month & Week & \multicolumn{3}{|c|}{$\%$ of the farmer } \\
\hline September & 3 & 8.69 & 3.57 & $0.63 \%$ \\
\hline September & 4 & 21.31 & 23.41 & $2.05 \%$ \\
\hline October & 1 & 63.78 & 58.73 & $9.26 \%$ \\
\hline October & 2 & 6.22 & 14.29 & $2.09 \%$ \\
\hline \multicolumn{2}{|c|}{ Total } & 100 & 100 & \\
\hline
\end{tabular}

\section{Variety used}

Black gram varieties sown by the farmers are presented in Table 3. All of the farmers of Sherpur used seeds of BARI Mas-3 where in Jamalpur $45 \%$ farmers used local variety. On an average, the highest (about 66\%) $\%$ of the farmers used purchased seeds from the market followed by own seed (34\%). The average seed rate per hectare of black gram cultivation was found to be 19.36 kilogram which was below the recommendation of 35-40 kilogram. Variety-wise yield was also observed and presented in Table 4. It was observed that BARI Mas-3 performed better in comparison to local variety sown in the survey plots.

Table 3. Variety used by the farmers

\begin{tabular}{|c|c|c|c|}
\hline \multirow[t]{2}{*}{ Variety } & Sherpur & Jamalpur & \multirow{2}{*}{$\begin{array}{l}\text { Variance between } \\
\text { respondents }\end{array}$} \\
\hline & \multicolumn{2}{|c|}{$\%$ of the farmer } & \\
\hline Local & - & 44.71 & $5.64 \%$ \\
\hline BARI Mas-3 & 100 & 55.29 & $6.36 \%$ \\
\hline Total & 100 & 100 & \\
\hline \multicolumn{4}{|l|}{ Source of seed } \\
\hline Purchased seeds & 56.52 & 75 & $11.76 \%$ \\
\hline Own seeds & 43.48 & 25 & $7.24 \%$ \\
\hline Seed rate $(\mathrm{kg} / \mathrm{ha})$ & 19.93 & 18.78 & $2.36 \%$ \\
\hline $\begin{array}{l}\text { Rec. seed rate } \\
(\mathrm{kg} / \mathrm{ha})\end{array}$ & \multicolumn{2}{|c|}{$35-40$} & \\
\hline
\end{tabular}

Table 4. Variety-wise yield of black gram

\begin{tabular}{l|c|c|c}
\hline Yield (Kg/ha) & Sherpur & Jamalpur & Variance between respondents \\
\hline Local & - & 953.67 & $6.07 \%$ \\
BARI Mas-3 & 1153.19 & 1188.64 & $5.23 \%$ \\
\hline
\end{tabular}


Use of chemical fertilizer: Use of chemical fertilizer by the farmers varied from location to location. Most of the farmers (about 71\%) used urea followed by DAP (17\%), TSP (6\%), and MoP (2\%) for black gram cultivation (Table 5). It is noted that there is no farmers found in both the areas used manure in their black gram field. It was found that the average dose of urea application was about 49 and $103 \mathrm{~kg}$ per hectare in Sherpur and Jamalpur district respectively. In Jamalpur district, the application of urea per hectare was found doubled than recommended dose. It was also found that, the farmers of Jamalpur district did not use MoP and DAP fertilizer. Among the different kinds of fertilizer used, the rate of urea application was found higher than those of other fertilizers and recommended dose also. In Sherpur area, farmers used all types of fertilizer with excessive rate of DAP (Table 5). Bangladesh Agricultural Research Institute recommended urea 40-50 kg, TSP 85-95 kg, MoP 30$40 \mathrm{~kg}$, and bio-fertilizer $4-5 \mathrm{~kg} \mathrm{ha}^{-1}$ for its varieties to produce $1.5-1.9 \mathrm{t} \mathrm{ha}^{-1}$ black gram (Anonymous, 2011).

Table 5. Location-wise fertilizer application by the sample farmers

\begin{tabular}{l|c|c|c}
\hline \multirow{2}{*}{ Fertilizer } & Sherpur & Jamalpur & Variance between respondents \\
\cline { 2 - 4 } & \multicolumn{3}{|c}{ \% of the farmer } \\
\hline Urea & 52.17 & 89.29 & $7.73 \%$ \\
TSP & 4.34 & 7.14 & $1.74 \%$ \\
MoP & 4.35 & - & $0.75 \%$ \\
DAP & 34.78 & - & $1.39 \%$ \\
\hline
\end{tabular}

Table 6. Average labor requirement (man-days/ha) for cultivation of black gram

\begin{tabular}{lcc}
\hline Location & No. of labour/ha & variance between respondents \\
\hline Sherpur & 38.58 & $5.31 \%$ \\
Jamalpur & 45.05 & $4.52 \%$ \\
\hline
\end{tabular}

\section{Economic profitability of black gram cultivation}

Profitability is one of the major criteria for determination of acceptance of a crop. A perusal of (Table 7) revealed that on an average cost of black gram cultivation was Tk. 55449 and Tk. $55502 \mathrm{ha}^{-1}$ in Sherpur and Jamalpur district, respectively. Study found that human labour, threshing, ploughing and cost of seeds cover the major fractions (70-74\%) of the total cost. Location-wise, there was no wide variation in the cost of black gram cultivation per hectare. Return to labour was found highest in Sherpur (Tk. 1000 head $^{-1}$ ) which indicate efficient utilization of labour input as it was the single highest cost involved input in black gram cultivation. Return to labour in Jamalpur was also found efficient, as it was also greater than that of the wage rate of labour. Benefit cost ratio was found better in both areas. It is thus revealed that pre boro period of black gram cultivation is a good profit earning enterprise. 
Table 7. Cost of production, return to labour and benefit cost ratio of black gram in the study areas

\begin{tabular}{l|c|c|c|c|c|c|c}
\hline Location & \multirow{2}{*}{$\begin{array}{c}\text { Average } \\
\text { cost ha }\end{array}$} & $\begin{array}{c}\text { Average } \\
\text { income ha }\end{array}$ & Return to & \multicolumn{3}{|c|}{ labour } \\
\cline { 5 - 6 } & & & & Min. & Max. & $\begin{array}{c}\text { Averag } \\
\text { e }\end{array}$ & $\begin{array}{c}\text { Coefficient of } \\
\text { variation (in } \\
\text { cost) }\end{array}$ \\
\hline Sherpur & 55449.47 & 82439.44 & 1000.23 & 1.36 & 1.88 & 1.49 & $13.40 \%$ \\
Jamalpur & 55502.01 & 75346.67 & 692.14 & 1.29 & 1.47 & 1.36 & $15.11 \%$ \\
\hline
\end{tabular}

\section{Comparative economic analysis with competitive crop}

The summary results of gross return, variable cost and gross margin per hectare and BCR (undiscounted) of black gram and mustard are presented in Figure 1. It shows that $\mathrm{ha}^{-1}$ gross return and gross margin of black gram were much higher than those of the mustard farming although the cost of production per hectare black gram farming was higher than that in mustard (Figure 1). From these discussions it is clear that both black gram and mustard farming were profitable, but black gram was more profitable than the mustard production in the char area of Jamalpur and Sherpur district. Thus, the standard of living of farmers as well as resource-poor people would be increased substantially since pulse and oilseed farming are highly remunerative to the char people.
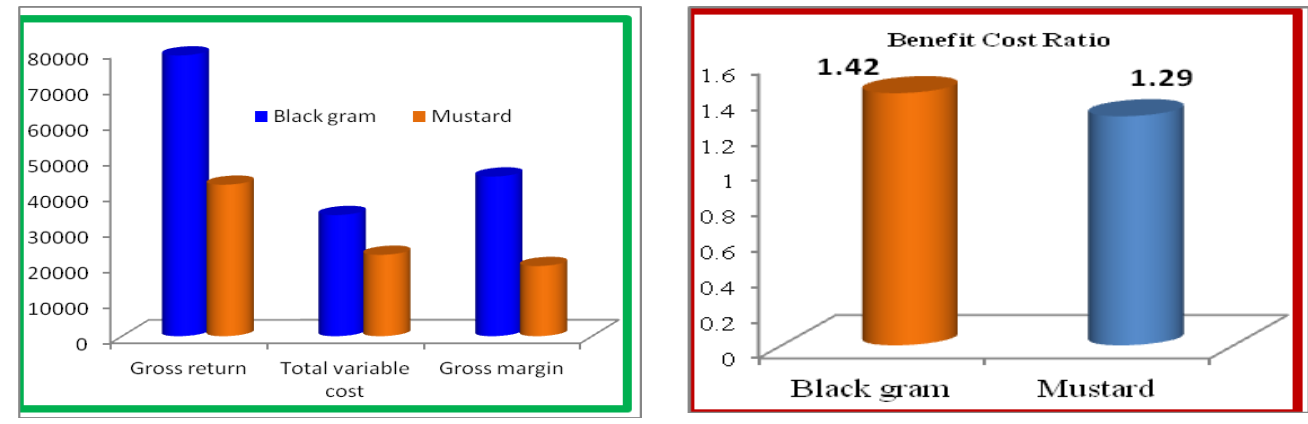

Figure 1. Comparative economic analysis with competitive crop

Source: Akter and Hossain, 2014

\section{Impact of black gram cultivation on farmers livelihood}

Livelihood asset: "A livelihood comprises the capabilities, assets and activities required for a means of living. A livelihood is sustainable when it can cope with and recover from stresses and shocks and maintain or enhance its capabilities and assets both now and in the future, while not undermining the natural resource base" (DFID, 2000). A livelihood is the set of capabilities, assets and activities that furnish the means for people to meet their basic needs and support their well being. Therefore the sustainable livelihood framework identifies five types of assets or capitals upon 
which livelihood are built, namely human capital, social capital, natural capital, financial capital and physical capital.

Table 8 shows the improvement of livelihood assets of selected farmers in the study areas. Majority of the farmers reported that quality of the components of human capital has increased over the periods through gaining education and knowledge, improving health condition, more access to nation, better training and development of skill in all the selected areas. Almost all farmers involvements in different social groups, their managerial capacity through black gram production had improved in the study areas.

Farmers' income had increased and they were able to have more cash savings and liquid assets through black gram farming along with crop farming, livestock rearing and fisheries. The condition of other major components of housing as well as safe sanitation such as drinking water and paka toilet also developed considerably.

The livelihood diversification is a process of change which varies from farmer to farmer and over the space and time (Ghosh et al., 2011). Therefore, the adoption of any technology is not exclusive, but one of the factors influencing the changes in livelihood of farmers. The rural livelihoods are also wide-ranging (Ashley et al., 2003). Both crop diversification and farm sector diversification lead to livelihood diversification influencing the rural economy; therefore, the adoption of appropriate agricultural technology holds the key for development of rural economy (Mehta, 2009).

Table 8. Changes in human capital, social capital, natural capital, financial capital and physical capital of farm household

(All are in \% of respondents' number)

\begin{tabular}{lc|cc}
\hline Components & Increase & Decrease & Constant \\
\hline \multicolumn{4}{c}{ Human capital } \\
\hline Health and sanitation & 61 & 14 & 25 \\
Education & 59 & - & 41 \\
Knowledge/efficiency & 23 & - & 77 \\
Access to information & 60 & - & 40 \\
\hline \multicolumn{4}{c}{ Social Capital } \\
Involved in social group/activities & 45 & 6 & 49 \\
Political involvement & 31 & 11 & 58 \\
Self managerial capability & 59 & 2 & 39 \\
Social access & 57 & 6 & 37 \\
Decision making ability & 67 & 3 & 30 \\
Women empowerment & 37 & - & 63 \\
\hline
\end{tabular}




\begin{tabular}{lr|cc}
\hline Components & Increase & Decrease & Constant \\
\hline \multicolumn{5}{c}{ Natural Capital } \\
\hline Cultivable land & 24 & 8 & 68 \\
pond & 10 & - & 90 \\
Tube-well water access & 47 & - & 53 \\
\hline \multicolumn{5}{c}{ Financial capital } \\
Cash in hand & 12 & - & 88 \\
Cash at Bank & 11 & - & 89 \\
Jewelry & 19 & 8 & 73 \\
\hline \multicolumn{5}{c}{ Physical Capital } & & \\
\hline Building & 3 & - & 97 \\
Tin roof & 49 & - & 51 \\
Motor cycle / bicycle/ motor van & 23 & 5 & 72 \\
Electricity & 39 & - & 61 \\
TV/Radio & 22 & 6 & 72 \\
Mobile phone & 53 & - & 47 \\
\hline
\end{tabular}

\section{Major categories of constraints to black gram cultivation}

Although black gram was observed to be a profitable crop, there exist lots of constraints to its higher production. The respondent farmers were asked about the various constraints faced by them in black gram production. The identified constraints were listed out and the farmers asked to rank those problems. The Garrett's ranking technique was used to combine the ranks given by all the farmers and to find out the final ranks. These results are presented in Table 9 and discussed below.

\section{Infrastructural constraints}

Infrastructural constraints comprised of four related constraints viz lack of irrigation facilities, non availability of high yielding varieties (HYV) of seeds at the time of sowing and non availability of plants protection chemicals in the market. Among these constraints, lack of irrigation facilities and non availability of HYV seeds of black gram at the time of sowing were the two major constraints faced by the farmers in production of black gram, in order to importance as perceived by the farmers (Table 9).

\section{Socio-economic constraints}

Table 9 reveals that six constraints were identified by the farmers as related to their socioeconomic conditions. Low price of black gram, Labour scarcity with high cost and high market toll on output were the major constraints in this category. 


\section{Technological constraints}

An analysis of the data presented in Table 9 reflects that lack of knowledge about improved varieties of black gram, seed rate, spacing, sowing date was ranked I, in order to importance as perceived by the farmers. Lack of knowledge about insect pest and disease management, lack of knowledge about fertilizer dosage and recommended method of its application, lack of knowledge about seed treatment and weed management were other major technological constraints identified by the farmers in the study areas. Similar have also been reported by Yadav et al., (2002).

Table 9. Major constraints in black gram cultivation as perceived by the farmers

\begin{tabular}{|c|c|c|c|}
\hline Constraints & $\begin{array}{l}\text { Total } \\
\text { score }\end{array}$ & $\begin{array}{l}\text { Mean } \\
\text { score }\end{array}$ & Rank \\
\hline \multicolumn{4}{|c|}{ Infrastructural constraints } \\
\hline a. Lack of irrigation facilities & 2817 & 704.25 & I \\
\hline $\begin{array}{l}\text { b. Non availability of plant protection chemicals in the } \\
\text { market }\end{array}$ & 2612 & 653 & IV \\
\hline c. Non availability of HYV seeds at the time of sowing & 2684 & 671 & II \\
\hline d. Non availability of good quality seed and fertilizers & 2621 & 655.25 & III \\
\hline \multicolumn{4}{|l|}{ Socio-economic constraints } \\
\hline a. Low output price & 3123 & 520.50 & I \\
\hline b. Labour scarcity with high cost & 3083 & 513.83 & II \\
\hline c. Non availability of credits in time & 2847 & 474.50 & IV \\
\hline d. High market toll on output & 3075 & 512.50 & III \\
\hline e. Lack of subsidy for inputs & 2582 & 430.33 & VI \\
\hline f. High cost of inputs & 2731 & 455.17 & $\mathrm{~V}$ \\
\hline \multicolumn{4}{|l|}{ Technological constraints } \\
\hline $\begin{array}{l}\text { a. Lack of proper knowledge about improved varieties, } \\
\text { seed rate, spacing and sowing date }\end{array}$ & 3115 & 623 & I \\
\hline b. Lack of knowledge about seed treatment & 2695 & 539 & IV \\
\hline $\begin{array}{l}\text { c. Lack of knowledge about fertilizer dosage and time of } \\
\text { application }\end{array}$ & 2932 & 586.4 & II \\
\hline d. Lack of knowledge about weed management & 2543 & 508.6 & $\mathrm{~V}$ \\
\hline $\begin{array}{l}\text { e. Lack of knowledge about insect pest and diseases } \\
\text { management }\end{array}$ & 2830 & 566 & III \\
\hline \multicolumn{4}{|c|}{ Environmental constraints } \\
\hline a. Excess rainfall after flowering & 1604 & 534.55 & I \\
\hline b. Low soil moisture at the time of sowing and fruiting & 997 & 332.33 & III \\
\hline
\end{tabular}




\begin{tabular}{lccc}
\hline Constraints & $\begin{array}{c}\text { Total } \\
\text { score }\end{array}$ & $\begin{array}{c}\text { Mean } \\
\text { score }\end{array}$ & Rank \\
\hline \multicolumn{1}{c}{ Institutional constraints } & 1425 & 475.11 & II \\
\hline \multicolumn{1}{c}{ Terminal draught } & 1811 & 603.55 & I \\
\hline $\begin{array}{l}\text { a. Weak research-extension farmer linkages } \\
\text { c. Lack of regulated market }\end{array}$ & 1411 & 470.33 & II \\
b. Non availability of suitable literature & 1149 & 383.11 & III \\
\hline
\end{tabular}

\section{Environmental constraints}

Table 9 reveals that three constraints were identified by the farmers as related to the meteorological conditions. Excessive rain after flowering, terminal draught and low soil moisture at the time of sowing and fruiting were the three major constraints in this category. Similar have also been reported by Joshi et al., (2002).

\section{Institutional constraints}

Regarding institutional constraints it was observed that there was a weak researchextension farmer linkage and there was no regulated market nearby where the villagers could sell their produce (Table 9). Weak research-extension-farmer linkage was ranked I and lack of regulated market was ranked II. The third in order in this category was non availability of suitable literature.

\section{Marketing constraints of black gram cultivation}

The farmers also faced some marketing related constraints in the study areas. An analysis of the data presented in Table 10 reflects that limited buyer is the main problem in the local market followed by price instability, absence of storage facilities and high market toll on output (Table 10).

Table 10. Marketing related constraints faced by the farmers

\begin{tabular}{lcccc}
\hline Constraints & Total score & Mean score & Rank \\
\hline Limited buyers or buyers syndicate & 3330 & 666 & I \\
Price instability & 2975 & 595 & II \\
Lack of storage facilities & 2560 & 512 & III \\
High market toll & 2480 & 496 & IV \\
\hline
\end{tabular}

\section{Farmers' attitudes towards black gram cultivation}

Almost all the farmers in the survey areas reported that they will increase black gram area in the next season. When asked about the intention to grow black gram in future, $63 \%$ farmers reported that higher yield and income encouraged them for continuing 
black gram cultivation. While $33 \%$ farmers in all the areas reported that they will grow black gram as it is easy to grow.

\section{CONCLUSION}

Black gram provided high return to investment. This crop is gaining popularity in the study areas very quickly due to its high yield potential. Appropriate level of input use and time of operation is important for achieving higher yield and profits, but the technology employed by the farmers were not at the level of recommendation. A good opinion came out from the sample farmers in the study areas that higher yield and income encouraged them for continuing black gram cultivation.

\section{RECOMMENDATION}

Traditional cultural practices are being followed by the farmers so, it is necessary to provide information regarding proper time of sowing, seed rate, fertilizer dose, etc. to the farmers. The findings of the present study provides the empirical feedback to NARS institute (such as BARI, BINA), Agricultural universities who work to develop high yielding varieties, DAE, BADC and various non-governmental organizations working in agricultural and allied departments to strengthen the research-extension farmers linkage by providing credible and timely information to the farming community.

\section{REFERENCES}

Afzal M.A., Baker M.A., and Rahman M.L. (1999). Lentil cultivation in Bangladesh. Lentil, Blackgram and Mungbean Development Pilot project, Pulses Research Station, BARI, Gazipur-1701.

Akter, N., and Hossain, S. (2014). Socioeconomic impact of BARI sarisha 14 in Jamalpur district. Annual research report 2013-14, Regional Agricultural Research Station, Jamalpur. Pp.11-16.

Anonymous. (2011). Krishi Projukti Hatboi (Handbook of Agri Technology), Fifth Edition, Bangladesh Agricultural Research Institute, Gazipur-1701. Bangladesh.

Ashley, C., Start, D., Slater, R., and Deshingkar, P. (2003). Understanding Livelihoods in Rural India: Diversity, Change and Exclusion. Policy Guidance Sheets produced by the Overseas Development Institute for the Livelihood Options Study, funded by the UK Department for International Development (DFID).

BARC. (2016). Crop calendar produced by Bangladesh Agricultural Research Council, Farmgate, Dhaka. Bangladesh.

BBS. (2014). Statistical Yearbook of Bangladesh, Bangladesh Bureau of Statistics, Ministry of Planning, Government of the People's Republic of Bangladesh, Dhaka.

BER. (2017). Bangladesh Economic Review, Department of Finance, Ministry of Finance, Government of the People's Republic of Bangladesh, Dhaka.

DFID. (2000). Department for International Development. Sustainable livelihood guidance sheets. Victoria Street, London, SW1E5JL, UK. 
EGIS. (2000). Environment and Geographic Information System. Riverine chars in Bangladesh-Environmental dynamics and management issues. Dhaka: EGIS, Environment and GIS Support Project for Water Sector Planning.

Ghosh, S., Kumar, A., James, B.K., Roy Chowdhury, S., Brahmanand, P.S., Mohanty, R.K., and Kar, G. (2011). Impact assessment of the technologies on the farming and livelihood of farmers. Research Bulletin No. 52, Directorate of Water Management (Indian Council of Agricultural Research), Bhubaneswar, Odisha. p56.

Gowda, C.L., Laxmipathi, S., Srinivasan, P., Gaur., M., and Saxena., K.B. (2013). Enhancing the Productivity and Production of Pulses in India. Indian Society of Pulses Research and Development, IIPR, Kanpur, India.

Hamjah, M.A. (2014). Climatic Effects on Major Pulse Crops Production in Bangladesh: An Application of Box-Jenkins ARIMAX Model, J. Economics and Sustainable Development. 5 (15).

HIES, (2010). Preliminary report of Household Income and Expenditure Survey. Bangladesh Bureau of Statistics, Ministry of Planning, GoB, Dhaka.

Huq, A.S.M., Hussain, A.M.S., Rashid, M.A., and Karim, M.R. (1998). Comparative profitability of potato under different situations in Dinajpur. Bangla. J. Agril. Res., 23: 81-95.

Islam, Q.M.S., Miah, M.A.M., Rahman, M.S., and Hossain, M.S. (2013). Adoption of BARI mung varieties and its constraints to higher production in southern region of Bangladesh. Bangladesh J. Agril. Res. 38(1):85-96.

Islam, Q.M.S., Firuz, J.M., Mohiuddin, M., and Choudhury, M.A.R. (2015). Financial analysis of lentil production-benefits and constraints: case for mid-western parts of Bangladesh. BJPST: 13(1): 044-049 [Jan, 2015]. Available online at http:/www.bjpst.net

Islam, Q.M.S., Rahman, M.S., Hossain, M.A., and Hossain, M.S. (2011). Economic analysis of mungbean (vigna radiata) cultivation in some coastal areas of Bangladesh. Bangladesh J. Agril. Res. 36(1):29-40.

Joshi, P.K., Pratap, S.B., and Vinay, A.B. (2002). Socioeconomic constraints and opportunities in rainfed rabi cropping in rice fallow areas in India, a policy paper submitted to ICRISAT, Andhra Pradesh, India.

Jukanti, A.K., Gaur, P.M., Gowda, C.L.L., and Chibbar, R.N. (2012). Nutritional quality and health benefits of chickpea (Cicer arietinum L.): a review. British Journal of Nutrition 108, S11-S26.

Kumar, S., and Bourai, V.A. (2012). "Economic Analysis of Pulses Production Their Benefits and Constraints"(A Case Study of Sample Villages of Assan Valley of Uttarakhand, India). IOSR Journal of Humanities and Social Science (IOSRJHSS) 1(4):41-53.

Kumar, P.R., Peshin, Nain, M.S., and Manhas, J.S. (2009 \& 2010).Constraints in pulses cultivation as perceived by The farmers. Rajsthan Journal of Extension Education. 17 \& 18: 33-36.

Mahesh, N. (2000). Economic constraints facing the Indian tea industry: Strategies for postWTO era. PhD thesis of the department of Agricultural Economics, University of Agricultural Sciences, Bangalore. 
Mehta, R. (2009). Rural Livelihood Diversification and its Measurement Issues: Focus India. Wye City Group on Rural Statistics and Agricultural Household Income, Second Annual Meeting, 11-12 June. FAO, Rome.

Miah, M.A.M., Akter, M.S., and Bakr, M.A. (2004). Status of pulses varieties adoption in Bangladesh: a farm level study. Bangladesh Journal of Agricultural Economics XXVII(2): 107-122

Niaz, M.F.R., Baten, M.A., Roy, A., and Hossain, M.M. (2013). Forecasting of Lentil Pulse Production: An Econometric Analysis. Australian Journal of Basic \& Applied Sciences, 7(2): 819-824.

Niaz, M.F.R., Aziz, M.A., Rahman, M.M., and Mohammad, N. (2013). Modeling on Grass Pea and Mung Bean Pulse Production in Bangladesh Using ARIMA Model. IOSR Journal of Agriculture and Veterinary Science. 6(1): 20-31.

Rahman, M.L., and Zilani, M.A. (2009). Agricultural Research Priority: Vision-2030 and beyond Bangladesh Agricultural Research Council, Farmgate. Dhaka, Bangladesh.

Yadav, S.S., Kumar, J., and Ram, H. (2002). Sustainable pulse production problems and Prospects. Intensive agriculture, 40: 10-12.

Yude, C., Kaiwei, H., Fuji, L., and Jie, Y. (1993). The potential and utilization prospects of kinds of wood fodder resources in Yunnan. Forestry Research 6, 346-350. 